\title{
Effect of dietary curries on the glycaemic index
}

\author{
S Pirasath ${ }^{1}$, K Thayaananthan ${ }^{2}$, S Balakumar ${ }^{3}$, V Arasaratnam ${ }^{4}$ \\ (Index words: glycaemic index, glycaemic response, fibre, basic foods, curries)
}

\begin{abstract}
Objective Determination of the glycaemic index (GI) of different basic foods in combination with different curries.

Methods Healthy volunteers $(n=20)$ of $21.05( \pm 0.92)$ years old, $53.90( \pm 9.36) \mathrm{kg}$ in body weight, $153.92( \pm 9.15) \mathrm{cm}$ in height and $20.55( \pm 2.22) \mathrm{kgm}^{-2}$ of body mass index were included. After overnight fasting, $75 \mathrm{~g}$ of glucose and each test food containing $75 \mathrm{~g}$ of digestible carbohydrate were administered and blood glucose level measured half hourly for two hours. The GI was calculated and analysed by randomised complete block design using SAS analytical package.

Results The mean GI values of parboiled rice ('Mottaikarupan') either with green leaf curry (Amaranthus) or gravy (soya meat) or green leaf curry and gravy were $47.47( \pm 11.21), 56.30( \pm 9.31)$ and $54.67( \pm 10.03) \%$ respectively. The mean $\mathrm{Gl}$ of 'kurakkan pittu' (Eleucine coracana) with the above curries were $57.51( \pm 5.52)$, $63.25( \pm 8.86)$ and $59.25( \pm 5.49) \%$ respectively. The mean GI of 'atta pittu' (whole wheat grain flour) with the above curries were $44.40( \pm 14.27), 50.80( \pm 9.35)$ and 46.29 $( \pm 8.90) \%$ respectively. The GI of parboiled rice or 'kurakkan pittu' or 'atta pittu' with green leaf curry differed significantly $(p<0.05)$ from other combined foods. The GI of parboiled rice or 'kurakkan pittu' or 'atta pittu' with gravy or green leaf curry and gravy did not differ significantly $(p>0.05)$ among them.

Conclusions 'Kurakkan pittu' is inferior to 'atta pittu' and parboiled rice. Including curries to basic foods altered the GI. Therefore, when dietary advice is given to diabetic patients, not only the basic foods, but also the curries to be consumed have to be considered.
\end{abstract}

Ceylon Medical Journal 2010; 55: 118-22

\section{Introduction}

The glycaemic index (GI) is an important parameter of food quality which compares the hyperglycaemic effect of a tested meal with pure glucose [1]. The blood glucose response to food is reflected by the GI of a particular food. GI is defined as the incremental area under the blood glucose response curve elicited over a two-hour period by a $75 \mathrm{~g}$ carbohydrate portion of a food, expressed as a percentage of the response to the same amount of carbohydrate from a standard food taken by the same person [2,3]. Food with a GI value of 70 or more are considered to be a high GI diet, with an index value between 55 to 69 as medium GI diet and less than 55 as low GI diet [4]. Reducing the glycaemic index of carbohydrate rich foods in diet may decrease the metabolic risk [5].

The objective of this study was to determine the GI of frequently consumed locally available different foods with various curries. 'Atta pittu' (whole wheat flour) and 'kurakkan pittu' (Eleucing coracana) are the suggested alternatives to rice for consumption by diabetic and cardiovascular disease patients. These two are suggested by the health professionals because of their high fibre contents. The evaluation of GI will help the local public to decide the diets which have to be consumed, particularly by diabetic and coronary heart diseases patients. Hence, in this study the GI of frequently consumed basic foods such as parboiled rice, 'atta pittu' and 'kurakkan pittu' either with green leaf curry or gravy made up of soya meat or green leaf curry and the gravy were studied.

\section{Methods}

Materials

Glucose (Royal pure glucose, Smithkline Beecham (Pvt) Ltd, Moratuwa), parboiled rice ('mottaikarupan' variety), 'atta' flour (whole wheat flour) (Anna International PTE Ltd., Colombo), green leaf (Amaranthus sp.), 'kurakkan' (Eleucine coracana), soy meat (Convenience Foods Lanka PLC, Ratmalana) were purchased from the local market.

\section{Preparation of foods}

Parboiled rice was prepared in appropriate amount of water without draining out the water. Roasted 'kurakkan' flour was mixed with salt (added to taste) and hot water, made into small particles and steamed. In similar manner 'atta pittu' was prepared from roasted 'atta' flour.

Amaranthus leaves were cleaned, washed well in running tap water and cooked with salt, green chillies, onions and small amount of first extract of coconut milk.

${ }^{1}$ Medical Student, and ${ }^{2}$ Department of Biochemistry, Faculty of Medicine, University of Jaffna, Sri Lanka.

Correspondence: SP, e-mail <selladuraipirasath81@gmail.com>. Received 30 July and revised version accepted 19 September 2009. Competing interests: none declared. 
Soya meat gravy was prepared with soya meat, coconut milk (third and first extracts), chilli powder and onions. For the experiment only the gravy was used without the soya meat.

\section{Foods combinations used and analysis}

Parboiled rice with green leaf curry (Amaranthus sp), parboiled rice with gravy and parboiled rice with green leaf curry and gravy were used. Similar combinations of 'kurakkan pittu' and 'atta pittu'were selected. All foods were analysed for their total sugar, total protein, moisture, fat and soluble dietary fibre, insoluble dietary fibre and total dietary fibre content $[6,7]$.

\section{Selection of participants}

A group of 20 healthy volunteers between 20 to 24 years of age was selected and the weight and height were determined and body mass index was calculated. The volunteers who had abnormal glucose tolerance, underweight or overweight, dieting or restricting their carbohydrate intake, suffering from any illness or food allergy were excluded from the study. The blood samples were collected and blood glucose levels were measured using semi-automated biochemical analyser (TC 3300). GI and glycaemic response were calculated [8]. GI of different types of foods were analysed by randomised complete block design using SAS analytical package.

\section{Results}

Mean age, weight, height and body mass index of the participants were $21.05( \pm 0.92)$ years, $53.90( \pm 9.36) \mathrm{kg}$, $153.92( \pm 9.15) \mathrm{cm}$ and $20.55( \pm 2.22) \mathrm{kgm}^{-2}$ respectively. When $75 \mathrm{~g}$ of glucose was orally administered to the volunteers, blood glucose level reached the peak value at $30 \mathrm{~min}$. The mean fasting blood glucose level was 86.25 $( \pm 3.63) \mathrm{mg} / \mathrm{dl}$ and the mean blood glucose level at $30 \mathrm{~min}$ was $153.75( \pm 13.67) \mathrm{mg} / \mathrm{dl}$. The mean peak glycaemic response for pure glucose was $67.35( \pm 12.97) \mathrm{mg} / \mathrm{dl}$. After overnight fasting (12-14 hours) $75 \mathrm{~g}$ digestible carbohydrate containing test foods were administered to volunteers on different days. All foods showed peak glycaemic response at $30 \mathrm{~min}$ (Table 1).

The GI of cooked parboiled rice with green leaf curry, gravy (soya meat), and green leaf curry and gravy (soya meat) were $47.47( \pm 11.20), 56.30( \pm 9.31)$ and $54.67( \pm 10.03)$ $\%$ respectively (Table 2). The mean GI values of 'kurakkan pittu' either with green leaf curry or gravy, or green leaf curry and gravy were $57.51( \pm 5.52), 63.25( \pm 8.86)$ and 59.25 $( \pm 5.49) \%$ respectively (Table 2$)$. The mean GI values of 'atta pittu' either with green leaf curry or gravy, or green leaf curry and gravy were $44.40( \pm 14.27), 50.80( \pm 9.35)$ and $46.29( \pm 8.90) \%$ respectively (Table 2$)$. The proximate compositions of cooked parboiled rice, green leaves curry and soya meat gravy are shown in (Table 3).

Table 1. Glycaemic response $(\mathbf{m g} / \mathrm{dl})$ of combined food items at $\mathbf{3 0}$ and 60 minutes

\begin{tabular}{|c|c|c|c|c|c|c|}
\hline \multirow[t]{4}{*}{ Foods } & \multicolumn{6}{|c|}{ Glycaemic response $(\mathrm{mg} / \mathrm{dl})$} \\
\hline & \multicolumn{6}{|c|}{ Curries } \\
\hline & \multicolumn{2}{|c|}{ Green leaf curry } & \multicolumn{2}{|c|}{ Soya meat gravy } & \multicolumn{2}{|c|}{$\begin{array}{c}\text { Green leaf curry and } \\
\text { soya meat gravy }\end{array}$} \\
\hline & 30min & $60 \mathrm{~min}$ & 30min & $60 \mathrm{~min}$ & 30min & $60 \mathrm{~min}$ \\
\hline Parboiled rice & $32.60( \pm 10.20)$ & $15.67( \pm 5.57)$ & $37.70( \pm 7.67)$ & $15.0( \pm 4.57)$ & $36.85( \pm 10.65)$ & $19.00( \pm 4.87)$ \\
\hline 'Kurakkan pittu’ & $38.45( \pm 7.10)$ & $16.00( \pm 5.16)$ & $42.80( \pm 12.55)$ & $24.33( \pm 6.16)$ & $39.75( \pm 7.26)$ & $25.67( \pm 7.16)$ \\
\hline 'Atta pittu' & $29.10( \pm 10.23)$ & $13.0( \pm 4.51)$ & $33.50( \pm 5.64)$ & $15.0( \pm 4.67)$ & $30.85( \pm 7.15)$ & $19.0( \pm 5.0)$ \\
\hline
\end{tabular}

Table 2. Proximate compositions of parboiled rice, 'kurakkan pittu', 'atta pittu', green leaves and gravy of soya meat

\begin{tabular}{lccccc}
\hline Constituents & Parboiled rice & 'Kurakkan pittu' & 'Atta pittu' & Green leaf curry & Gravy of soya meat \\
\hline Moisture & $65.54( \pm 0.63)$ & $40.50( \pm 0.78)$ & $55.0( \pm 0.48)$ & $89.00( \pm 0.07)$ & $88.50( \pm 0.09)$ \\
Total protein & $2.18( \pm 0.02)$ & $4.11( \pm 0.11)$ & $5.69( \pm 0.10)$ & $1.66( \pm 0.11)$ & $1.75( \pm 0.07)$ \\
Total digestible & $23.10( \pm 0.2)$ & $35.39( \pm 0.17)$ & $27.07( \pm 0.03)$ & $1.63( \pm 0.34)$ & $2.94( \pm 0.05)$ \\
carbohydrate & & & & & \\
Total dietary fibre & $2.30( \pm 0.03)$ & $4.97( \pm 0.1)$ & $4.50( \pm 0.06)$ & $8.47( \pm 0.13)$ & $3.17( \pm 0.10)$ \\
Soluble dietary fibre & $0.80( \pm 0.01)$ & $0.79( \pm 0.01)$ & $0.87( \pm 0.04)$ & $1.41( \pm 0.03)$ & $1.19( \pm 0.03)$ \\
Insoluble dietary fibre & $1.50( \pm 0.03)$ & $4.18( \pm 0.1)$ & $3.63( \pm 0.05)$ & $7.06( \pm 0.13)$ & $1.98( \pm 0.09)$ \\
\hline
\end{tabular}


Table 3. Nutrients and the glycaemic index of the different foods

\begin{tabular}{|c|c|c|c|c|c|c|c|}
\hline Basic food & Curries consumed & $\begin{array}{l}\text { Total } \\
\text { digestible } \\
\text { carbohydrate } \\
(\mathrm{g})\end{array}$ & $\begin{array}{l}\text { Total } \\
\text { dietary } \\
\text { fibre } \\
(g)\end{array}$ & $\begin{array}{l}\text { Soluble } \\
\text { dietary } \\
\text { fibre } \\
\quad(g)\end{array}$ & $\begin{array}{l}\text { Insoluble } \\
\text { dietary } \\
\text { fibre } \\
(\mathrm{g})\end{array}$ & $\begin{array}{l}\text { Protein } \\
\text { (g) }\end{array}$ & $\begin{array}{l}\text { Glycaemic } \\
\text { index } \\
(\%)\end{array}$ \\
\hline \multirow[t]{3}{*}{$\begin{array}{l}\text { Parboiled rice } \\
\text { (325g) }\end{array}$} & Green leaf curry $(50 \mathrm{~g})$ & 75.89 & 11.72 & 3.31 & 8.41 & 7.92 & $\begin{array}{r}47.47 \\
( \pm 11.20)\end{array}$ \\
\hline & Gravy (30g) & 75.96 & 8.45 & 3.20 & 5.37 & 7.61 & $\begin{array}{r}56.30 \\
( \pm 9.31)\end{array}$ \\
\hline & $\begin{array}{l}\text { Green leaf curry }(50 \mathrm{~g}) \\
\text { and Gravy }(30 \mathrm{~g})\end{array}$ & 76.77 & 12.69 & 3.90 & 8.90 & 8.44 & $\begin{array}{r}54.67 \\
( \pm 10.03)\end{array}$ \\
\hline \multirow[t]{3}{*}{$\begin{array}{l}\text { 'Kurakkan } \\
\text { pittu' (212g) }\end{array}$} & Green leaf curry $(50 \mathrm{~g})$ & 75.84 & 14.78 & 2.38 & 12.39 & 9.54 & $\begin{array}{r}57.51 \\
( \pm 5.52)\end{array}$ \\
\hline & Gravy (30g) & 75.91 & 11.51 & 2.27 & 9.355 & 9.24 & $\begin{array}{r}63.25 \\
( \pm 8.86)\end{array}$ \\
\hline & $\begin{array}{l}\text { Green leaf curry }(50 \mathrm{~g}) \\
\text { and Gravy }(30 \mathrm{~g})\end{array}$ & 76.72 & 15.75 & 2.98 & 12.89 & 10.07 & $\begin{array}{r}59.25 \\
( \pm 5.49)\end{array}$ \\
\hline \multirow[t]{3}{*}{$\begin{array}{l}\text { 'Atta pittu' } \\
\text { (277g) }\end{array}$} & Green leaf curry $(50 \mathrm{~g})$ & 75.80 & 16.71 & 3.12 & 13.59 & 16.59 & $\begin{array}{r}44.40 \\
( \pm 14.27)\end{array}$ \\
\hline & Gravy (30g) & 75.87 & 13.45 & 3.00 & 10.56 & 16.29 & $\begin{array}{r}50.80 \\
( \pm 9.35)\end{array}$ \\
\hline & $\begin{array}{l}\text { Green leaf curry }(50 g) \\
\text { and Gravy }(30 \mathrm{~g})\end{array}$ & 76.68 & 17.68 & 3.71 & 14.09 & 17.12 & $\begin{array}{r}46.29 \\
( \pm 8.90)\end{array}$ \\
\hline
\end{tabular}

The GI of parboiled rice with green leaf curry differed significantly ( $p<0.05$ ) from parboiled rice either with gravy or green leaf curry and gravy. The GI of parboiled rice either with gravy or green leaf curry and gravy did not differ significantly $(p>0.05)$ among them. The GI value of 'kurakkan pittu' with green leaf curry and 'kurakkan pittu' with gravy was significantly different $(p<0.05)$. The GI of 'kurakkan pittu' either with green leaf curry or green leaf curry and gravy did not differ significantly $(p>0.05)$ among them. The GI of 'kurakkan pittu' either with gravy or green leaf curry and gravy did not differ significantly ( $p>0.05$ ) among them. The GI of 'atta' flour pittu with gravy differed significantly $(p<0.05)$ from 'atta' flour pittu either with green leaf curry or green leaf curry and gravy. The GI of 'atta' flour pittu either with green leaf curry or green leaf curry and gravy did not differ significantly $(p>0.05)$ among them.

\section{Discussion}

The GI of same amount of digestible carbohydrate containing cooked parboiled rice, 'kurakkan pittu'and the 'atta pittu' with green leaf curry were $47.47( \pm 11.21)$, $57.51( \pm 5.52)$ and $44.40( \pm 14.27) \%$ respectively. Based on the GI, parboiled rice and the 'atta pittu' with green leaf curry were low glycaemic index diets while, 'kurakkan pittu' with green leaf curry was medium GI diet. The parboiled rice and 'atta pittu' with green leaf curry and gravy were low GI $[54.67( \pm 10.03)$ and $46.29( \pm 8.65)]$ diets. The parboiled rice with gravy was a GI index diet $[56.30( \pm 8.38)]$. The 'kurakkan pittu' in combination with green leaf curry, gravy [63.25 ( \pm .87$)]$, and green leaf curry and gravy [59.25 ( \pm 5.49$)]$ was forming medium GI diets. According to previous study 'kurakkan pittu' has a higher GI (80) than rice flour (64) [9]. Our results showed the same. Among the different combinations of diets studied with three different basic foods and three different combinations of curries, 'atta pittu' with green leaf curry is the best choice. Consumption of parboiled rice and 'kurakkan pittu' are acceptable with green leaf curry alone for those who need a low GI diet. Even though the above diets are selected for the diabetic and coronary heart disease patients, recommendation of the diets should be made after analysing their GI, glycaemic load and energy contents.

The composition of the food or the meal will influence the blood glucose response. Further foods within the same classification can have different glycaemic indices. For example, the different varieties of potatoes, cereals showed variations in glycaemic indices $[9,10,11]$. Further more 
processing of the food influence the GI. During cooking gelatinisation of starch takes place, the cell walls are ruptured and the starch molecules are released [12]. Therefore structural integrity of cell wall and starch granules also determine the glycaemic index.

However, the methods of preparations of 'atta pittu' and 'kurakkan pittu' were same. The moisture contents of the both preparations varied significantly. But the GI of 'kurakkan pittu' was higher than that of 'atta pittu' with different combinations of curries. When the moisture content of the food is high the digestion of the food will be easier and hence the glucose release into the blood will be quicker [10]. However, this phenomenon could not be accepted because the moisture content of 'atta pittu' is lower than that of 'kurakkan pittu' and the GI value of 'atta pittu' is lower than that of 'kurakkan pittu' . Further the moisture content of parboiled rice is the highest and its GI value is in between those of 'atta pittu' and 'kurakkan pittu' .

When the total dietary fibre, soluble dietary fibre and insoluble dietary fibre contents are considered in the different basic diets in combination with different curries, no direct correlations with the changes in the GI were observed (Tables 2 and 3). An increase in the total fibre content of food can delay the glycaemic response [13]. Fibre delays the digestion of starch in the stomach, transition time of the stomach contents to the duodenum, delay the diffusion of different saccharides in the duodenum, delay the hydrolysis of polysaccharides in the duodenum and delay the absorption of monosaccharides through the microvillai of the epithelial cells of the jejunum and the upper part of the ileum [14]. Total dietary fibre content has a significant negative correlation with GI [15].

Based on the results, the 'atta pittu' was the best basic food having lowest GI with all different combinations of curries. With green leaf curry, the low GI was obtained with all the basic foods. When consumed with gravy alone, the GI of all the basic foods increased (Tables 3). The results from this study indicated that the GI of the diet does not depend only on the type of the basic food but also on the side dishes consumed. From the results it can be concluded that glycaemic index of a mixed diet is influenced by the ingredients included in the curries.

Digestibility of sorgum, winged bean and horse gram was not influenced when it was supplemented with the red chilli, cumin, black pepper, coriander, garlic, asafoetide, dry ginger and ajowan $[16,17]$. The digestibility of proteins of different legumes was decreased by chilli and coriander [18]. Therefore it is not possible to support the increase in glycaemic index of the food combinations with gravy, due to added spices. Inclusion of gravy to the different basic foods increased the GI. This may be due to the increased digestibility with high moisture content of the foods [10]. However, further research on this observation is necessary.

\section{Conclusion}

Parboiled rice either with green leaf curry or green leaf curry and gravy, 'atta pittu' either with green leaf curry or gravy, or green leaf curry and gravy are lower GI diets (GI values $<55 \%$ ). Parboiled rice with gravy, 'kurakkan pittu' either with green leaf curry or gravy or green leaf curry and gravy are medium GI diets (GI values between 55 to $70 \%$ ). 'Atta pittu' is the best choice for patients with diabetes and coronary heart disease followed by parboiled rice. Even though 'kurakkan pittu' was thought to be a good meal for these patients, it is inferior to 'atta pittu' and parboiled rice. Consumption of green leaf curry significantly reduces the rise in blood sugar level.

\section{Acknowledgements}

Financial assistance was given by IRQUE medical study programme and Research fund of Faculty of Medicine, University of Jaffna.

The approval for this study was obtained from the Ethical Review Committee, Faculty of Medicine, University of Jaffna, Sri Lanka.

\section{References}

1. Chlup R, Bartek J, Reznickova M, et al. Determination of glycaemic index of selected foods (white bread and cereal bars) in healthy persons. Biomedical Papers 2004; 148: 17-25.

2. Anderson GH. Sugars and health. Nutrition Research 1997; 17: $1485-98$.

3. Wolver TMS. Dietary recommendations for diabetes: high carbohydrate or high monounsaturated fat? Nutrition Today 1999; 34: 73-7.

4. Mendosa D. Glycaemic Index. 2007; http://www.mendosa.com/gi:htm.

5. Vrolix R, Van Meijl LEC, Mensink RP. The metabolic syndrome in relation with the glycaemic index and the glycaemic load. Physiology and Behaviour 2008; 90: 293-9.

6. Pearson D, ed. The Chemical Analysis of Foods. 7th ed. Edinburgh, London, Churchill. Livingstone, 1976.

7. Megazyme. Total dietary fibre assay procedure. (http:// www.megazyme.com/booklets/KTDFR.pdf, 2007.

8. Wolewer TMS. The glycaemic index: methodology and clinical implications. The American Journal of Clinical Nutrition 1990; 54: 846-51.

9. Thathvasuthan A, Chandrasekara DG, Wijesinghe NG, Jayawardena HMDK. The effect of types of cereal on the glycaemic response of two traditional Sri Lankan food items. Tropical Agriculture Research 2007; 19: 101-9.

10. Fernandes G, Velangi A, Wolewer TMS. Glycaemic index of potatoes commonly consumed in North America. Journal of the American Diebetic Association 2005; 105: 557-62. 
11. Frei M, Siddhuraju P, Becker K. Studies on the in vitro starch digestibility and the glycaemic index of six different indigenous rice cultivars from the Philippines. Food Chemistry 2003; 83: 395-402.

12. Wandsnider LA. The roasted and the boiled: food composition and heat treatment with special emphasis on Pil-Hearth cooking. Journal of Anthropological Archaeology 1997; 16: $1-48$.

13. Marangoni F, Poli A. The glycaemic index of bread and biscuits is markedly reduced by the addition of a proprietary fiber mixture to the ingredients. Nutrition, Metabolism and Cardiovascular Diseases 2008; 18: 602-5.

14. Nishimune T, Yalcushiji T, Summoto T, et al. Glycaemic response and fiber content of some foods. American Journal of Clinical Nutrition 1991; 54: 414-9.

15. Hettiarachchi UPK, Ekanyake S, Welihinda J. Do Sri Lankan meals help decrease blood glucose response? Ceylon Medical Journal 2009; 54: 39-43.

16. Pradeep KU, Geervani P, Eggum BO. Influence of spices on utilization of sorgum and chickpea protein. Plants Foods and Human Nutrition 1991; 41: 269-76.

17. Pradeep KU, Geervani P. Influence of spices on protein utilization of winged bean (Psophocarpus tetragonolobus) and horse gram (Dolichos biflorus). Plant Foods and Human Nutrition 1994; 46: 187-93.

18. Prakash VHP, Prakash J. In vitro proteins digestibility of legumes cooked with spices. Food 1999; 43: 19-21. 